\title{
Kurumsal İtibar ve Kuramsal Temelleri
}

\section{Corporate Reputation and Theoretical Foundations}

\author{
Belgin BAHAR, Galatasaray Üniversitesi, Türkiye, belginkaygan@gmail.com
}

\begin{abstract}
Öz: Günümüzün yoğun rekabet ortamında kurumsal itibar, şirketler için önemli bir rekabet üstünlüğü sağlama unsuru olarak stratejik yönetim sürecinde yer almaktadır. Artık uzun dönemli ve sürdürülebilir başar hedefleyen şirketler itibar yönetimi ve kurumsal sosyal sorumluluk gibi konulara daha çok önem vermeye başlamışlardır.

Bu makalenin amacı kurumsal itibar kavramını irdeleyerek, yönetimsel açıdan önemini ve etkilerini incelemektir. Bu bağlamda kurumsal itibarın, yazında temellendirildiği kuramlar yardımıyla nasıl açıklanıp anlamlandırıldığ tartışılmıştır. Çalışma sonucunda, farklı disiplinler ve kuramsal temellendirmeler baz alındığında itibarın örgütsel etki ve sonuçlarının değiştiği görülmüştür. Ayrıca yeni bir itibar oluşum modeli önerilerek çeşitli teoriler birleştirilmeye çalışılmıştır. İtibarın nasıl oluştuğunu ve teoriler tarafindan ne şekilde açıkladığını anlamak özellikle kurumsal itibar yönetimi açısından da önem taşımaktadır.
\end{abstract}

Anahtar Sözcükler: Kurumsal İtibar, İşaret Kuramı, Meşruiyet Kuramı, Kaynak Tabanlı Görüş, Paydaş Kuramı, Kurumsal Kuram

Abstract: In today's intense competition environment, corporate reputation is a part of the strategic management process as an element providing a significant competitive advantage for companies. Companies that aim to achieve long-term and sustainable success have begun to give more importance to issues such as reputation management and corporate social responsibility.

The aim of this article is to examine the concept of corporate reputation and to understand its importance and effects in terms of management. In this context, it has been discussed how corporate reputation is explained and justified with the help theories based on the literature. As a result of the study, it has been seen that the organizational impact and results of reputation have changed in different disciplines and theoretical foundations. As a new reputation formation model was also proposed and tried to combine several theories. Understanding how reputation is formed and how it is explained by theories are important in terms of corporate reputation management.

Keywords: Corporate Reputation, Reputation Management, Signaling Theory, Legitimacy Theory, Resource-Based View, Stakeholder Theory, Institutional Theory

\section{Giriş}

Günümüzde şirketlerin ürün ve hizmetleri ile rekabet üstünlüğü sağlamasının yanında, bu üstünlüğün sürdürülebilirliği pazar dış1 güçleri yönetme yeteneklerine bağlı olarak değişmektedir. Bu bağlamda paydaş ve itibar yönetimi, kuruluşların rekabet avantajının sürdürülebilirliğini sağlayan pazar dışı stratejiler arasında ele alınabilir (Mahon, Heugens ve Lamertz, 2004).

Kurum itibarı sosyal paydaşların duygu, düşünce ve izlenimlerini yansıtan algılamalardan meydana gelmektedir (Karaköse, 2007). Kurumların başarısında büyük öneme sahip olan kurumsal itibar, hesap verilebilirlik, çevreye duyarlılık, sözünde durma, şeffaflık, müşseri memnuniyeti, etik şirket politikaları gibi uygulamalarla güçlenebilir. Pek çok çalışma güçlü bir kurumsal itibarın şirketlere finansal performans (Carmeli ve Tishler, 2005) ve kriz yönetimi (Tucker ve Melewar, 2005) gibi farklı alanlarda olumlu etkiler yarattığını göstermiştir.

Son 20 yılda kurumsal itibar, yönetim yazınında pek çok araştırmaya konu olarak büyük ilgi görmektedir (Rindova, Williamson, Petkova, 2010). Buna rağmen kavramın soyut yapısından dolayı hala tanımında, boyutlarında ve kuramsal alt yapısında eksiklikler olduğu görülmektedir (Barnett, Jermier ve Lafferty, 2006; Aydemir, 2008). Bu nedenle, kompleks ve çok boyutlu bir kavram olan itibarı incelemek için daha fazla araştırma yapılmasına ihtiyaç vardır (Deephouse, 2000). Saylı ve Uğurlu da (2007) bu konuda kavramsal ve görgül çalışmaların yetersizliğine dikkat çekmişlerdir. Özellikle ülkemizde kurumsal itibar konusunda mevcut çalışmalar daha çok tanımlayıcı (deskriptif) nitelikte olup araştırma varsayımlarının dayandırılacağı kuramların ön plana çıktığı çalışma sayısı çok sınırlıdır. Mevcut araştırmalar arasında Aydemir (2008) itibarı önemli bir rekabet aracı olarak nitelendirmiş ve kaynak tabanlı bakış yaklaşımı ile ele almıştır. Çakır ise (2009) itibar-örgütsel doku ilişkisini incelediği araştırmasında itibarı paydaş kuramı bağlamında sentezlemiştir.

$\mathrm{Bu}$ araştırmada öncelikle kavramın yapısı irdelenecek, daha sonra yazında farklı kuramsal yaklaşımlarda ve disiplinlerde konunun nasıl ele alındığı incelenecektir. Böylelikle kurumsal itibar kavramının kuramsal temellerinin daha iyi anlaşılması sağlanarak örgütsel sonuç bağlantılarını kurmak amaçlanmaktadır.

\section{Kurumsal İtibar Kavramı}

Son yıllarda stratejik yönetim yazınında kurumsal itibar konusunda kavramsal ve ampirik çalışmaların çoğalmasıyla kavramının önemi arttığı görülmektedir (Brammer ve Pavelin, 2006). Bir kurumun en değerli varlığı olan itibar, kurumun sosyal paydaşların gözünde nasıl algılandığını ifade eden değerler bütünü şeklinde tanımlanabilir. Charles J. Fombrun'a (1996) göre kurumsal itibar, "bir kurumun tüm hedef kitlesine yönelik olarak ve rakipleriyle kıyaslandığında genel görüntüsünü oluşturan geçmiş eylemleri ve gelecek görüntüsünün algısal temsilidir”. 
Bir başka tanım, itibarın değer yaratma ile ilişkisini vurgulamaktadır. Rindova vd.’nin (2005: 1033) yaptığı tanıma göre itibar, paydaşların bir örgütün rakiplerine göre değer yaratma yetenekleri hakkındaki algılarıdır. Rindova ve arkadaşları, kurumsal itibarı iki boyuttan oluşan bir kavram olarak ele almaktadırlar. Bu boyutlar: algılanan kalite ve ün olarak belirtilmiştir. İtibarın algılanan kalite boyutu, paydaşların bir örgütün kaliteli mal üretebileceğine dair algılarını ifade ederken, ün boyutu paydaşların aklına önce gelmeyle ilgilidir. Ayrıca bu çalışmada çeşitli alanlardaki itibar tanımlarını özetledikleri tablo incelendiğinde, farklı yaklaşımlara rağmen tanımların iki noktada birleştiği görülmektedir: Öncelikle itibar, bilgi, izlenim, alg1 ve inançlar gibi sosyal bilişleri ifade etmektedir. Bu sosyal bilişler ise, diş gözlemcilerin zihninde yer almaktadır (Rindova, Williamson, Petkova, 2010).

Barnett, Jermier ve Lafferty (2006) 49 adet araştırmada yapılan kurumsal itibar tanımlarını inceleyip üç ana grup altında toplamışlardır:

- "Bilinirlik" (awareness) olarak adlandırılan grupta yer alan tanımlarda itibar, paydaş algılarına dayanan atıfları içermektedirler.

- "Değerlendirme" (assessment) grubundaki tanımlar, itibar kavramına yargı, tahmin, değerlendirme veya ölçü şeklinde atıfta bulunmaktadırlar.

- "Varlık" (asset) olarak adlandırılan üçüncü gruptaki tanımlar itibarı, firma için değer ve önem yaratan bir kavram olarak ele almaktadırlar. Bu grupta itibar, bir kaynağa, maddi veya maddi olmayan bir varlığa işaret etmektedir.

Tüm bu gruplandırmalardan sonra yazarlar itibarı "bir gözlemcinin, zamanla şirkete atfedilen finansal, sosyal ve çevresel etkilerin değerlendirilmesine dayanan bir şirkete yönelik toplu yargılar" şeklinde tanımlamıştır (Barnett, Jermier ve Lafferty, 2006).

Fombrun ve van Riel (1997) ise itibar kavramının farklı disiplinlerde nasıl ele alındığını incelemiştir ve altı farklı disiplin perspektifinden kurumsal itibarı tanımlamıştır.

- İktisadi (ekonomist) perspektiften itibar, bir işaret olarak görülmektedir.

- $\quad$ Stratejik bakış açısına göre itibar, değerli bir soyut varlıklardır.

- Pazarlama perspektifinden itibar, çoğunlukla marka imajı olarak adlandırılır ve müşteri açısından konuyu ele alır.

- Örgütsel perspektiften itibar, iç paydaşların örgüt algısı ve deneyimini ifade etmektedir.

- Sosyolojik görüşe göre itibar, meşruiyet göstergesidir. Bir firma performansının kurumsal bir alandaki beklenti ve normlara göre toplam değerlendirmelerini yansıtmaktadır.

- Muhasebe perspektifinden itibar maddi olmayan ve finansal değer kazandıran bir varlık şeklinde ele alınmaktadir.

Kurumsal itibar, yazında sıkça imaj ve kimlik kavramlarıyla eş anlamlı olarak kullanılmaktadır. Fombrun ve van Riel (1997) kurum kimliğini itibar ve imaj kavramlarından ayıran en önemli unsurun, kimliğin özellikle iç paydaşlara yönelik olması olduğunu belirtmişlerdir. Kurum imajı ise daha çok dış paydaşların algılarıyla ilgilidir. Yazarlar, itibarın bu algıların toplanmasının net sonucu olduğunu belirtmektedirler. Diğer bir deyişle kurumsal itibar; tüm paydaşların kuruma yönelik görüşlerini, iç kimliği ve dış imajı da kapsayan bütüncül bir kavram olarak değerlendirilebilmektedir (Davies vd., 2003).

Ural (2002), imaj ve itibarın iş hayatında kazananları ve kaybedenleri belirleyen en önemli unsurlardan biri haline geldiğini vurgulamıştır (Ural, 2002). Günümüzde şirketler oluşturulması uzun yıllar süren ancak kaybedilmesi de bir o kadar kolay olan kurumsal itibar ve yönetimi konusuna daha önem verir hale gelmişlerdir. Warren Buffett'ın ünlü sözü de bunu doğrular niteliktedir: "İtibarı oluşturmak yirmi yıl, onu mahvetmek beş dakika alır" (The Huffington Post, 2013). Bu bağlamda Uzunoğlu ve Öksüz (2008), kurumların itibarının daimî risk altında olduğunu ve yapılandırılmış planlarla kurumsal itibar riskini yönetmenin gerekliliğini belirtmişlerdir. İtibar risklerini yönetmek elbette zordur ancak bu riskler etkin bir şekilde yönetilemezse gelirlerin düşmesi, maliyetlerin artması, tedarikçi ve müşterilerin kaybedilmesi, iyi çalışan sirkülasyonun artması gibi olumsuz sonuçların doğması kaçınılmazdır (Uzunoğlu ve Öksüz, 2008).

Yukarıda bahsedilenler doğrultusunda itibarı kazanmak kadar korumanında güç olduğunu belirtebiliriz. Kurumsal itibar yönetiminin aynı zamanda bir itibar riski yönetimi olduğunu göz önünde bulundurarak sürecin etkin bir şekilde yönetilmesi güçlü bir kurumsal itibar oluşturmada önem arz etmektedir.

Karatepe (2008) şirketlerde kurumsal itibar yönetiminin kazandığı önemi şu şekilde açıklamıştır: 1900’lerin başlarında yöneticilerin planlama, örgütleme, düzenleme, denetleme gibi klasik görevleri bulunmaktaydı. Zamanla bu işlevlere, halkla ilişkiler, yenilikçilik ve değişim yöneticiliği gibi yeni kavramlar eklenmiştir. Günümüzde ise; üst düzeydeki bir yöneticinin temel görevi, kamuoyunda her yönüyle "iyi bir şirket" izlenimi yaratmak ve bunu sürdürmektir. Dolayısıyla kurumsal itibarın yönetimi şirketler açısından elzem bir konudur.

Pek çok araştırmacı güçlü bir kurumsal itibarın firma için çok olumlu sonuçlar doğuracağını belirtmiştir (Brammer ve Milligton, 2005; Boyd vd., 2010). Seitel (2016) kurumsal itibarın şirkete sağladığı yararları şu şekilde ifade etmiştir: Müşterileri ürünleri almaları ve başkalarına tavsiye etmek için ikna etmek, yatırımcıları yatırım yapmaları için kuruluşa çekmek, yetenekli çalışanları firmaya çekmek, güçlü ortaklarla iş birliği üstünlüğü sağlamak ve kriz anında insanlardan destek görmek.

Özetle, itibar kavramı sınırları tam olarak çizilemeyen ve birçok komşu kavramla iç içe geçen bir olgu olarak nitelenebilir. Farklı disiplinlerden araştırmacıların farklı kuramları temel alarak bu kavramın içini doldurmaya, sınırlarını çizmeye, süreci tanımlamaya ve etkilerini test etmeye çalıştıkları görülmektedir. 
$\mathrm{Bu}$ makalede yazında farklı kuramlara göre kurumsal itibarın örgütsel açıdan ne gibi sonuçlar doğurduğu tartışılacaktır. Kurumsal itibarın kuramsal dayanaklarını analiz etmek kavramın daha iyi anlaşılmasını sağlayacaktır.

\section{Kuramsal Yaklaşımlar ile Kurumsal İtibar İlişsisi}

Çeşitli disiplinlerden farklı kuramlar kullanan araştırmacılar, kurumsal itibarın farklı öncüllerini ve sonuçlarını ele almışlardır. Örneğin Walker (2010) 54 makaleyi incelediği çalışmasında kurumsal itibarı tanımlarken en çok 3 kuramın kullanıldığını tespit etmiştir. Bunlar: kurumsal kuram, işaret kuramı ve kaynak tabanlı bakış modelidir. Yazar bu kuramları itibarı açıklaması bakımından eylem öncesi, eylem ve eylem sonrası şeklinde sınıflandırmıştır. Bu kategorizasyona göre kurumsal kuram, şirketlerin itibarı inşasında nasıl meşruiyet kazandıklarını incelemek için, yani özellikle "eylem öncesi”" aşamasını anlamlandırmak amacıyla kullanılmaktadır. İşaret kuramı ise, genellikle "eylem aşaması"nda kullanılarak itibarın oluşturulması, sürdürülmesi ve korunması konularını kapsamaktadır. Bu bağlamda firmaların stratejik tercihlerinin, paydaş algılarının oluşmasında rol oynayan işaretleri nasıl temsil ettiği incelenmektedir. Son olarak kaynak tabanlı bakış perspektifinden itibar, değerli bir soyut kaynaktır ve rekabet üstünlüğü sağlaması açısından özellikle "eylem sonrası" aşamasında kullanılmaktadır.

Aşağıdaki bölümlerde kurumsal itibar kavramının kuramsal altyapılarından yola çıkarak farklı disiplinlere göre etkileri ve sonuçları açıklanmaya çalışılacaktır.

\subsection{Kurumsal Kuram Açısından Kurumsal İtibar}

Kurumsal itibarı tanımlarken günümüzde en çok kullanılan kuramlar arasında kurumsal kuram ve ona bağlı olarak da meşruiyet kuramı yer almaktadır. Kurumsal kuram, bir kurum ve çevresi arasındaki etkileşimleri inceleyen, kurumsal yönetim felsefesi içindeki temel yaklaşımlardan biridir.

Kurumsal kurama göre, paydaşların şirketlerden farklı beklentileri vardır. Şirketler bu beklentileri karşılayarak içinde bulundukları çevreye uyum sağlamaya çalışırlar. Şirketlerin çevreden destek görmeleri, devamlılıkları ve meşruiyet kazanmaları kurumsal çevreye olan uyuma bağlıdır (Meyer ve Rowan 1977; DiMaggio ve Powell 1983; Suchman, 1995).

Pfeffer ve Salancik (1978), şirketlerin çeşitli paydaşlardan nasıl destek aldığını anlamak için onların da birer parçası oldukları daha geniş sosyal bağlamlarla nasıl ilişkilendiğine dikkat etmek gerektiğini belirtmiştir. Bu bağlamda şirketlerin içinde bulundukları çevre, kurumsal düzenlemelerin şekillenmesinde etkili olan önemli unsurlardan biridir.

Yeni kurumsal kuramın öncüleri Meyer ve Rowan'ın (1977) çalışmalarını takip eden DiMaggio ve Powell (1983), kurumların neden benzer hale geldikleri sorusuna yanıt aramışlardır. Buna cevap olaraksa yazarlar, homojenleşme sürecinde en büyük etkinin meşruiyet amacıyla gerçekleşen eşbiçimcilik olduğuna işaret etmektedirler.

Kurumsal kuram felsefesinin temelinde, örgütlerin yapı ve süreçlerinin, içinde bulundukları kurumsal çevreye uyumları sonucu biçimlendiği yatmaktadır. Örgütlerin yaşamlarını sürdürebilmeleri için, teknik anlamda verimli olmalarının yanında, bu çevredeki kurumlara uyarak kendilerini meşru kılmaları gerekmektedir. Sonuçta, aynı örgütsel alanda yaşayan örgütler, kendilerine özgü ussal gerekliliklerden bağımsız olarak benzer kurumlara uymak zorunda olduklarından, yapısal açıdan eşbiçimli hale gelmektedirler (Özen, 2007). Yeni kuramsal kuramda eşbiçimcilik olarak karşımıza çıkan bu benzeşme süreci, farklı şirketlerin benzer özellikler göstererek homojenleşmesini açıklamak için kullanılmaktadır. Meyer ve Rowan (1977) kurumsal yaklaşımda eşbiçimciliği şu şekilde açıklamaktadır: Örgütlerin mevcut faaliyet alanlarında rasyonalize edici mitler oluştuğunda, örgütler yapılarını bu mitlerle eşbiçimli olacak şekilde geliştirirler. Herhangi bir örgütsel yapı başta farklılıklar içerebilir. Ancak zamanla bu kurumsal alan içinde örgütleri birbirine benzemeye iten baskılar oluşmaktadır (Meyer ve Rowan, 1977). Bu ifadeden anlaşılacağı üzere Meyer ve Rowan, kurumsal olarak yerleşmiş uygulamaları ve değerleri rasyonelleşmiş mitler olarak kabul ederler.

DiMaggio ve Powell (1983) çalışmalarında eşbiçimciliğe neden olan 3 tip baskıdan söz etmektedirler. Bunlar; yasal yükümlülüklerden doğan zorlayıcı eşbiçimcilik, mesleki baskılardan kaynaklanan normatif eşbiçimcilik ve başarılı örgütlerin örnek alınmasıyla oluşan öykünmeci eşbiçimciliktir (DiMaggio ve Powell, 1983).

Yukarıda da bahsedildiği gibi, yeni kurumsal kuramın en önemli amaçlarından biri, şirketlerin içinde bulundukları çevrenin bir parçası olmasını sağlayarak meşruiyet kazanmalarıdır (Meyer ve Rowan, 1977). Bu nedenle kurumsal kuram ile meşruiyet kuramı birbirlerini tamamlar niteliktedir. Suchman (1995) meşruiyet kuramını, bir kurumun faaliyetlerinin; içinde bulunduğu toplumsal normlara, değerlere, inançlara uyumlu olarak ve istenen, doğru ya da uygun bulunan şekilde gerçekleştirilmesi algısı ya da varsayımı olarak tanımlamıştır. Bu kurama göre, kurumlar itibarlarını arttıracak faaliyetler ile varlıklarını meşrulaştırmakta ve çevrelerinden kabul görmektedirler.

Kurumsallaşmanın meşruiyet dışında şirketlerin itibarı üstünde de etkisi vardır. Diğer bir deyişle eşbiçimci baskılar sonucu kurumsallaşan firmalar meşruiyet ve itibarla ödüllendirilirler (Wright ve Rwabizambuga, 2006). Bu bağlamda itibar ve meşruiyet kavramları arasındaki ilişkiye dikkat çekmek gerekir. King ve Whetten (2008) meşruiyet ve itibar kavramlarını, bir kurumun eylemlerinin paydaşların değerlendirmelerine dayalı olarak onaylanma algısı şeklinde tanımlamaktadır. Her iki kavram, firmaların performanslarını artırmak için kullandıkları maddi olmayan varlıklar arasındadır. Ancak bu kavramlar arasında önemli farklılıklar bulunmaktadır. Meşruiyet, kuruluşların sosyal beklentilere ve standartlara uygun olduğu algısı iken itibar, kuruluşları benzerlerinden ayırmaya dayanmaktadır (King ve Whetten, 2008). Diğer bir deyişle, meşruiyet kurumlar arasındaki benzerliklere odaklanırken, itibar kurumlar arasındaki farklılıklarla ilgilenmektedir (Bitektine, 2011; Petkova, 2016). 
Kısacası, kurumsallaşma ve meşruiyet kazanma şirketlerin için itibar oluşumunda önem taşımaktadır. Kurumsal itibarın soyut yapısı gereği yazında sıkça dayanaklandırıldığı bir diğer kuram kaynak tabanlı bakıştır.

\subsection{Kaynak Tabanlı Bakış Açısından Kurumsal İtibar}

İtibar maddi olmayan ancak finansal bir sonucu olan stratejik bir kaynaktır (Boyd vd. 2010). Bu bağlamda itibar, sürdürülebilir rekabet avantajı sağlaması nedeniyle her geçen gün stratejik yönetimde daha fazla dikkat çekmektedir (Deephouse, 2000). Pek çok çalışma (örnek olarak: Bergh vd., 2010; Boyd vd. 2010) kurumsal itibarı kaynak tabanlı bakış açısı ile temellendirerek ele almaktadır.

Kaynak tabanlı bakış, rekabet üstünlüğünü sağlayan asıl unsurların şirkete özgü kaynak ve yetenekler olduğunu savunur (Barney, 1991). Bu kaynaklar somut ve soyut varlıklar ile örgütsel yetenekler olmak üzere üç grupta sınıflandırılabilir (Collis ve Montgomery, 1998). Somut varlıklar, bina, makineler ve ham maddeler gibi bilânçoda gösterilebilen fiziksel varlıklardır. Soyut varlıklar genellikle elle tutulamayan ve bilânço üzerinde görülme $\neg$ yen kurumsal itibar, marka ismi, bilgi gibi taklit edilmesi zor kaynaklardır. Örgütsel yetenekler ise; bir şirketin belirli faaliyetleri rakiplerinden daha iyi yapabilme veya kaynaklarını daha iyi kullanabilme kapasitesi şeklinde tanımlanabilir (Collis, 1994).

Barney (1991) şirketlerin tüm kaynaklarının sürdürülebilir rekabet avantajı yaratmadığını, bir kaynağın bu özelliğe sahip olabilmesi için değerli, kıt, taklit edilemez ve ikamesiz olması gerektiğini belirtmiştir (Barney, 1991). Bu dört özelliğin tamamına sahip olan kaynaklar "stratejik kaynaklar" şeklinde nitelendirilebilir (Combs ve Ketchen, 1999). Flanagan ve O'Shaughnessy'in de (2005, s.445) belirttiği gibi "itibar belki de en önemli stratejik kaynaklardan biridir.”

Taklit edilmesi zor bir kaynak olarak kurumsal itibar şirketlere önemli rekabet üstünlükleri sunmaktadır. Öncelikle kurumsal itibar, şirketlere farklılaşma imkânı sağlayan unsurlardan biridir. Gerçekten büyük ve köklü şirketlerin defter değeri ile piyasa değerleri arasında uçurumlar olabilmektedir. Bu değer defterde gösterilmese bile şirketlere büyük ve uzun süreli rekabet üstünlüğ̈̈ sağlamaktadır.

Araştırmalar kurumsal itibar ile ekonomik sonuçlar arasında da olumlu bir ilişki olduğunu göstermektedir. Güçlü bir kurumsal itibar pazarda güçlü bir pazarlık imkânı ve ortaklarla anlaşmalarda üstünlükler sağlayarak ticari faaliyetlerdeki maliyetleri düşürmektedir (Bergh vd., 2010). Kurumsal itibarın bir diğer sonucu, firmanın gelirlerini arttırmasına katkı sağlaması ve finansal performansını iyileştirmesidir (Deephouse, 2000). Özetle, küreselleşmenin sonucu gittikçe artan rekabet ortamında kurumsal itibar, dikkatle yönetilmesi gereken stratejik bir kaynak olarak karşımıza çıkmaktadır.

\section{3. İşaret Kuramı Açısından Kurumsal İtibar}

1973 yılında ünlü iktisatçı Michael Spence tarafından geliştirilen işaret kuramı, emek piyasasında işveren ve işçi arasında asimetrik bilgi sorununun var olduğu durumlarda, işçilerin eğitimlerini birer işaret aracı olarak kullanarak işverenlere kalitelerini belli etmesi üzerine kurulu bir kuramdır. Dolayısıyla bu kurama göre, karar vericiler bir kurum ya da ürünleri hakkında yeterince bilgiye sahip olmadıkları durumlarda şirketlerin gönderdikleri işaretlere göre onlar hakkında bir izlenim edinerek değerlendirme yaparlar.

Walker (2010) işaret kuramının sadece firmalar tarafından gönderilen stratejik işaretleri incelemediğini, aynı zamanda bu işaretlerin paydaşlar tarafından nasıl yorumlandığını da incelediğini belirtmiştir. İtibar oluşumunu işaretleşme süreciyle açıklamaya çalışanlar arasında Basdeo ve meslektaşları (2006) ve Fombrun ve Shanley (1990) bulunmaktadır. Onlara göre firmalar stratejik tercihleri ve eylemleri ile gözlemcilere işaret göndermektedir ve gözlemciler de bu işaretleri kullanarak firmalar hakkında izlenimler oluşturmaktadır. Bu sürecinin sonunda ise itibar oluşmaktadır (Basdeo vd., 2006; Fombrun ve Shanley, 1990).

Fombrun ve Shanley (1990), paydaşların şirketlerden çeşitli işaretlerle itibar değerlendirmeleri yapmasına ilişkin bir model önermiştir. Bu modele göre paydaşlar firmalar hakkında piyasa, muhasebe, kurumsal ve strateji işaretleri beklemektedirler. Piyasa ve muhasebe işaretleri, şirketlerin ekonomik performanslarıyla ilgili olup, onların piyasa performansını ve kar politikalarını temsil etmektedir. Kurumsal işaretler içerisinde kurumsal sahiplik, sosyal sorumluluk, medya görünürlüğü ve firma büyüklüğü gibi firmayı çekici kılan unsurlar yer almaktadır. Son olarak stratejik işaretler arasında şirketlerin kurumsal duruşlarını tanımlayan farklılaşma stratejileri bulunmaktadır. Fombrun ve Shanley geliştirdikleri bu itibar modelini Fortune 500 içinde yer alan 292 şirketten elde edilen verilerle test etmiştir. Araştırmanın sonuçları, şirketlerin, bilgi asimetrisinden dolayı itibar açısından rekabetçi bir pazarda olduklarını ve bu nedenle şirketlerin temel özelliklerini paydaşlara işaret kuramıyla gösterdiklerini desteklemektedir (Fombrun ve Shanley, 1990).

Basdeo ve meslektaşları (2006) ise şirketlerin kurumsal performanslarını, şirketlerin temel yetkinlikleri hakkında bilgi veren ve bu şekilde paydaş değerlendirmelerini etkileyen işaretler olarak gördüklerini ifade etmişlerdir. Kurumsal itibarın da bu eylemlerin sonucu olarak şekillendiğini belirtmişlerdir.

İtibar, şirketlerin paydaşlara gönderdiği önemli bir güven işareti olarak değerlendirilebilir (Powell, 1990; Shapiro, 1983). Kavram özellikle ürün kalitesiyle ilgili bilgi asimetrisi olan pazarlarda önemlidir (Weigelt ve Camer, 1988). Örneğin yazılım sektörü gibi teknoloji şirketleri için itibarın önemi büyüktür. Weick (1990), müşterilerin ürünleri satın almadan önce kalitesini değerlendirmesindeki güçlükten bahsetmiş ve bu gibi uzmanlık gerektiren sektörlerde bilgi asimetrisi olduğunu belirtmiştir. Müşteriler bu sektörlerdeki ürünlerin kalitesi hakkında bilgi sahibi olmadıkları için 
karşılaştırma ve değerlendirme yapmakta zorlanırlar. Bu zorluğu aşmak içinse genellikle ürünlerin geçmiş dönemdeki algılanan kalitesini ve markaların itibarını kullanırlar (Vendelo, 1998).

Benzer şekilde Helm ve Mark (2007) işaret kuramına odaklandıkları araştırmalarında, olumlu itibarın müşterilerin riskini azaltması ve yeni ürünlerin benimsenmesi üzerindeki etkilerini ortaya koymuşlardır.

Rekabetin artmasıyla birlikte kurumsal itibar yönetimi şirketler için daha önemli bir konu haline gelmiştir. Artık paydaşlar şirketleri değerlendirirken, şirketlerin sosyal sorumluluk faaliyetlerini ve topluma ilişkin kurumsal sosyal performanslarını da dikkate almaktadırlar. Bu nedenle kurumsal itibarın açıklanmasında yararlanılan bir diğer kuram paydaş kuramıdır.

\subsection{Paydaş Kuramı Açısından Kurumsal İtibar}

Kurumsal itibarın paydaş algısına dayanmasından dolayı yazında araştırma varsayımlarının desteklendiği kuramlardan biri de paydaş kuramıdır. Freeman 1984 yılında yayımladığı "Stratejik Yönetim: Paydaş Kuramı” isimli kitabıyla, şirketlerin kimi temsil ettiği sorusunu cevaplandırmaya çalışmış ve paydaş kuramının temelini atmıştır. Bu doğrultuda Freeman'ın "paydaş modeli” tüm pay sahiplerini önemseyen ve onların beklentilerine, zamanla değişen ihtiyaçlarına kulak veren bir felsefe olarak ortaya çıkmıştır (Ertuğrul, 2008).

Freeman (1984: 25) paydaşı "organizasyonun örgütsel amaçlarının gerçekleştirilmesini etkileyen ya da bu amaçların gerçekleştirilmesinden etkilenen kişi ya da grup” ş̧eklinde tanımlamış ve paydaş gruplarını hükümetler, politik gruplar, hissedarlar, ticari birlikler, tüketiciler, çalışanlar, tedarikçiler, rakip şirketler vb. şekilde sınıflandırmıştır. Bir başka tanıma göre ise paydaşlar, kurumun kararları, amaçları, faaliyetleri, uygulamaları ve politikalarını etkileyebilen ve bunlardan etkilenebilecek olan bireyler ve gruplar olarak açıklanabilir (Nemli, 2000: 76).

Freeman’ın (1984) öne sürdüğü paydaş kuramına göre, kurumların hedef kitleleriyle ortak birtakım amaçları bulunmaktadır ve bu amaçları gerçekleştirip rekabet üstünlüğü elde edebilmeleri için kurumların iç ve dış çevresiyle güçlü ilişkiler kurmaları gerekmektedir.

Paydaş kuramı, şirketlerin kurumsal sosyal performansları ile finansal performansları arasındaki ilişkiyi incelemek için kuramsal bir çerçeve sunmaktadır. Firmalar, belli bir düzeyde, paydaş taleplerini karşılamayı iş yapmanın zorunlu bir maliyeti olarak görmelidir (Ruf vd., 2001). Öyle ki, rekabetin artmasıyla birlikte toplumun ihtiyaç ve beklentilerini de dikkate alma gerekliliği paydaşların önemini arttırmıştır. Böylece şirketler ekonomik birer varlık olmanın yanı sıra sosyal bir boyut kazanmışlardır (Carroll, 2008; Frederick, 1994). Böylelikle kurumların sosyal sorumluluklarına ve bunların nasıl hayata geçirileceğine ilişkin sorulara cevap veren kurumsal sosyal sorumluluk ve kurumsal duyarlılık kavramlarından ortaya kurumsal sosyal performans kavramı çıkmıştır (Neville, Bell ve Mengüç, 2005). Neville, Bell ve Mengüç (2005) paydaş kuramını temel aldıkları araştırmalarında kurumsal itibarın kurumsal sosyal performans ve finansal performans arasındaki ilişkide önemli bir rol oynadığını göstermişlerdir. Araştırma modeline göre, kurumsal sosyal performans arttıça kurumsal itibar artmaktadır ve kurumsal itibar da finansal performansı olumlu etkilemektedir.

Paydaşlar, etkileşim içinde oldukları kurumlar hakkında beklentilere sahiptirler. Paydaş algıları, bu beklentilerin kurum tarafından ne ölçüde karşılandığı, kurumun paydaşları memnun edip etmediğinin paydaşlar tarafından değerlendirilmesi sonucunda oluşmaktadır (Dilsiz, 2008). Bu algılar bütünü ise kurum itibarını meydana getirmektedir.

Öte yandan Cable ve Graham (2000), paydaş bakış açısını benimseyerek ele aldıkları araştırmalarında, önemli bir paydaş grubunu oluşturan iş arayan kişilere odaklanmışlardır. Bu doğrultuda yazarlar, iş arayanların itibar algılarını nelerin etkilediğini incelemişlerdir. Araştırma sonuçlarına göre, bir firmanın faaliyet gösterdiği sektör türünün, firmanın çalışan gelişimi için sunduğu firsatların ve örgüt kültürünün iş arayanların itibar algılarını etkileyen faktörler arasında olduğunu ortaya konulmuştur.

Tablo 1 yazında yer alan çeşitli itibar araştırmalarının kullandıkları kuramlar ve araştırma sonuçlarına, Fombrun ve van Riel'in (1997) farklı disiplinlere göre yaptıkları sınıflandırma entegre edilerek derlenmiştir. Bu tabloda yer alan araştırmalar incelendiğinde son yıllardaki çalışmaların kurumsal itibarın, kurumsal sosyal sorumluluk ve kurumsal finansal performans arasındaki ilişkilere ağırlık verdiği görülmektedir. 
Tablo 1. Kurumsal İtibar Çalışmalarının Kuram ve Disiplinlere Göre Sınıflandırılması

\begin{tabular}{|c|c|c|c|c|}
\hline Kuram & Disiplin & Yazarlar & Копи & Araştırma sonuçlart \\
\hline $\begin{array}{l}\text { Kaynak tabanlı } \\
\text { bakış }\end{array}$ & $\begin{array}{l}\text { Stratejik } \\
\text { yönetim }\end{array}$ & Deephouse, 2000 & $\begin{array}{l}\text { Medya itibarının performans } \\
\text { üzerindeki etkileri } \\
\text { araştırılmıştır. }\end{array}$ & $\begin{array}{l}\text { Medyada sunulan bir firmanın genel değerlendirmesi olarak tanımladıkları } \\
\text { medya itibarının rekabet avantajı elde etme ve finansal performansı arttırma } \\
\text { gibi olumlu sonuçları bulunduğu ortaya konulmuştur. }\end{array}$ \\
\hline $\begin{array}{l}\text { İşaret kuramı ve } \\
\text { kurumsal kuram }\end{array}$ & İktisat & $\begin{array}{l}\text { Rindova, } \\
\text { Williamson, } \\
\text { Petkova ve Sever, } \\
2005\end{array}$ & $\begin{array}{l}\text { İtibarın boyutları, öncülleri } \\
\text { ve sonuçları inceleniyor. }\end{array}$ & $\begin{array}{l}\text { İtibarın, algılanan kalite ve ün/tanınma olmak üzere iki boyutu vardır. } \\
\text { Girdilerin kalitesi arttıkça algılanan kalite artmaktadır, bunun sonucunda ise } \\
\text { alıcı maliyetleri düşerken ve müşterilerin güveni artmaktadır. Böylece olumlu } \\
\text { itibar daha yüksek fiyatlara olanak sağlaması sayesinde örgüt performansının } \\
\text { ve ekonomik getirilerin artmasını sağlamaktadır. }\end{array}$ \\
\hline $\begin{array}{l}\text { İşaret kuramı }+ \\
\text { kurumsal kuram }\end{array}$ & $\begin{array}{l}\text { İktisat ve } \\
\text { sosyoloji }\end{array}$ & $\begin{array}{l}\text { Brammer ve } \\
\text { Milligton, } 2005\end{array}$ & $\begin{array}{l}\text { Kurumsal itibar ve sosyal } \\
\text { hayırseverlik arasındaki ilişki }\end{array}$ & $\begin{array}{l}\text { Araştırma bulguları daha yüksek düzeyde hayırseverlik harcamaları yapan } \\
\text { şirketlerin daha iyi bir itibara sahip olduklarını ve bu etkinin sektörler arasında } \\
\text { önemli ölçüde farklılık gösterdiğini göstermektedir. }\end{array}$ \\
\hline $\begin{array}{l}\text { Kaynak tabanlı } \\
\text { bakış }\end{array}$ & $\begin{array}{l}\text { Stratejik } \\
\text { yönetim }\end{array}$ & Boyd vd., 2010 & $\begin{array}{l}\text { İtibar ve performans ilişkisi } \\
\text { inceleniyor. }\end{array}$ & $\begin{array}{l}\text { Rindova, Williamson, Petkova ve Sever (2005)'in modeli yeniden test } \\
\text { edilmiştir. Bunun sonucunda itibarın geliştirilmesinin önerilenden daha } \\
\text { karmaşı bir yapıda olduğu sonucuna ulaşmışlarıdr. Bu araştırmada test edilen } \\
\text { modelin Rindova, Williamson, Petkova ve Sever (2005)'inkinden farkı ise, ün } \\
\text { boyutunun itibar ile performans arasında aracılık rolü oynamasıdır. }\end{array}$ \\
\hline $\begin{array}{l}\text { İşaret kuram }+ \\
\text { Bilişsel yanlılık } \\
\text { kuramı }\end{array}$ & $\begin{array}{l}\text { Pazarlama ve } \\
\text { sosyal } \\
\text { psikoloji }\end{array}$ & $\begin{array}{l}\text { Bartikowski ve } \\
\text { Walsh, } 2011\end{array}$ & $\begin{array}{l}\text { Kurumsal itibar ile müşteri } \\
\text { odaklı sonuçlar arasındaki } \\
\text { nedensellik ilişkileri } \\
\text { incelenmiştir. }\end{array}$ & $\begin{array}{l}\text { Araştırma sonuçları, müşteri bağlılığı ve sadakatin, müşteri odaklı kurumsal } \\
\text { itibar ile müşteri vatandaşlığı davranışları arasındaki ilişkiye aracılık ettiğini, } \\
\text { yani şirkete yardımcı olduğunu göstermektedir. }\end{array}$ \\
\hline $\begin{array}{l}\text { Sosyal kimlik } \\
\text { kuramı }\end{array}$ & $\begin{array}{l}\text { Örgütsel } \\
\text { Davranış }\end{array}$ & Helm, 2011 & $\begin{array}{l}\text { Çalışanların itibar inşasıında } \\
\text { oynadığ rol araştırılmıştır. }\end{array}$ & $\begin{array}{l}\text { Kurumsal itibar çalışanlarda duyulan gururu arttırırken; bu gurur çalışan } \\
\text { memnuniyeti, bağlılığı, itibar oluşumundaki etkilerin farkındalığ ile güçlü bir } \\
\text { șekilde ilişkilidir. }\end{array}$ \\
\hline $\begin{array}{l}\text { Paydaş kuramı + } \\
\text { kimlik kuramı }+ \\
\text { meşruiyet kuramı }\end{array}$ & Pazarlama & $\begin{array}{l}\text { Stanaland, Lwin } \\
\text { ve Murphy, } 2011\end{array}$ & $\begin{array}{l}\text { KSS'yi tüketici } \\
\text { perspektifinden inceleyerek, } \\
\text { KSS'nin öncülleri ve } \\
\text { sonuçlarına odaklanmıştır. }\end{array}$ & $\begin{array}{l}\text { Bu çalışmanın bulguları, KSS'nin kurumsal itibar, tüketici güveni ve tüketici } \\
\text { sadakatini olumlu yönde etkilediğini göstermektedir. }\end{array}$ \\
\hline Kurumsal Kuram & Sosyoloji & Petkova, 2016 & $\begin{array}{l}\text { Paydaşların pazara yeni } \\
\text { girecek firmalar hakkında } \\
\text { itibar algılarının oluşumu } \\
\text { incelenmiştir. }\end{array}$ & $\begin{array}{l}\text { Farklı pazar belirsizlikleri altında sektöre yeni giren firmalara yönelik paydaş } \\
\text { algılarının üç aşamalı oluşum sürecini açıklamışlardır. Bunlar: dikkat çekme, } \\
\text { meşruiyet oluşturma, potansiyel değer yaratma algısıdır. }\end{array}$ \\
\hline
\end{tabular}


Yukarıdaki bilgiler 1şı̆̆ında Fombrun ve van Riel'in (1997) yaptıkları 6 alan sınıflamasından iktisat ve sosyoloji disiplinlerinin, kurumsal itibarın oluşumuna etki eden faktörleri açıklamaya yaradığı belirtilebilir. İtibar oluşumu açıklanırken ise en çok işaret kuramı ve kurumsal kuramdan faydalanıldığı görülmektedir.

Tablo 2. İtibar oluşumuna etken faktörleri açıklayan kuram ve disiplinler

\begin{tabular}{|l|l|l|}
\hline Disiplin & Kuram & Itibar Oluşumuna Etkiler \\
\hline İktisat & İşaret kuramı & Çeşitli işaretlerle paydaş izlenimlerinin oluşması \\
\hline Sosyoloji & Kurumsal kuram & Çevreye uyum, benzeşme sonrası itibar oluşması \\
\hline
\end{tabular}

Fombrun ve van Riel'in (1997) yaptığı sınıflamadan geri kalan dört disiplinin ise kurumsal itibarın sonuçlarını açıklamak için kullanıldığı görülmektedir. Buna göre stratejik yönetim akademisyenleri (Barney, 1991, 2001; Deephouse, 2000; Rindova, 2001) kaynak tabanlı bakış yaklaşımını kullanarak olumlu itibarın rekabet üstünlüğü kazanmada ve finansal performansı arttırmada etkilerini incelemiştir. Pazarlama disiplininde marka imajı ve marka değeri konularıyla iç içe geçen itibar kavramı, tüketici bağlılığını arttırarak marka sadakati oluşumunda etki eden bir faktör konumundadır. Örgütsel davranış disiplini ise, paydaş kuramını kullanarak olumlu itibar sonucunda iç paydaşların bağlılığının arttırılması konularına odaklanmaktadır. Son olarak muhasebe alanı da yine itibarı soyut bir kaynak olarak ele alırken kaynak tabanlı bakış ile itibarı açıklamakta ve finansal performans sonuçları ile ilgilenmektedir.

Tablo 3. İtibarın sonuçlarını açıklayan kuram ve disiplinler

\begin{tabular}{|l|l|l|}
\hline Disiplin & Kuram & İtibarın Sonuçları \\
\hline Stratejik yönetim & Kaynak tabanlı bakış & $\begin{array}{l}\text { Sektörde rekabet üstünlüğü ve finansal } \\
\text { performansın artması }\end{array}$ \\
\hline Pazarlama & Paydaş kuramı & Müşteri sadakatinin artması \\
\hline Örgütsel davranış & Paydaş kuramı & Çalışan bağlılığının artması \\
\hline Muhasebe & Kaynak tabanlı bakış & Finansal performansın artması \\
\hline
\end{tabular}

Tüm bu yazın taraması ve sınıflandırmalardan yola çıkarak çeşitli disiplinlere ait kuramların birlikte kullanıldığı yeni bir kurumsal itibar oluşum süreci önerilmiştir (Şekil 1).

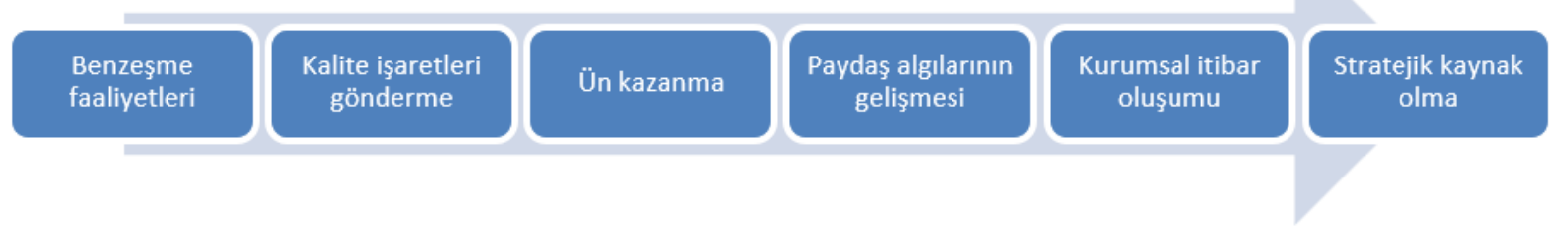

Şekil 1. Kurumsal İtibar Oluşum Süreci

$\mathrm{Bu}$ modele göre kurumsal itibar oluşumu öncelikle çevresel baskılar sonucu şirketlerin birbirine benzeşme faaliyetleriyle başlamaktadır. Bu benzeşme sürecinin sonunda paydaşların gözünde şirketlerin meşruiyetleri artmaktadır. Çevre ile uyum sağlayan şirketler, işaret kuramına bağlı olarak paydaşlarına çeşitli kalite işaretleri gönderdikçe bilinirliklerini arttırmaktadırlar. Gönderilen kalite işaretleri sonucunda paydaşların zihninde kurum hakkında izlenimler oluşmaktadır. Tüm bu algılar sonucu ortaya çıkan kurumsal itibarın en önemli sonucu ise, şirketler için taklit edilmesi zor, stratejik bir kaynak haline gelerek rekabet avantajına katkı sağlamasıdır.

\section{Sonuç}

Kurumsal itibarın oluşumu ve örgütsel sonuçları pek çok farklı disiplinde tartışılmakla birlikte, yazında kuramsal alt yapısının vurgulandığı çalışma sayısı sınırlıdır. Bu çalışma ile kurumsal itibarın kuramsal alt yapısı incelenerek örgütsel etkileri ve sonuçları ortaya konulmaya çalışılmıştır. Bu doğrultuda literatürdeki çalışmalar incelendiğinde kurumsal itibarın özellikle kurumsal kuram, kaynak tabanlı bakış, işaret kuramı ve paydaş kuramı ile açıklanmaya çalışıldığı görülmüştür. 
Yeni kurumsal kuramcılara göre, kurumları birbirine benzemeye iten esas etken, sosyal çevredeki politik ve kurumsal baskılardır. Bu uyumu sağlayan şirketler toplum nezdinde kabul görüp itibar ve meşruiyet kazanabilirler. Bu açıdan kurumsal kuram, itibarın oluşumunu anlamamızı sağlamaktadır. Öte yandan kurumsal kuramın temel yapı taşı olan meşruiyet kuramı da itibarın etkilerini anlamada yarar sağlamaktadır. Meşruiyet kuramına göre güçlü bir kurumsal itibar, bir şirketin yasallaşarak çevresine uyum sağlamasını kolaylaştırmaktadır.

Kurumsal itibar ile ilişkilendirilen bir başka kuram işaret kuramıdır. Bu kurama göre, şirketler yaptıkları eylemlerle paydaşlarına işaretler göndermekte ve bu işaretler sonucu algıyı şekillendirerek itibarı oluşturmaktadırlar. Çeşitli kalite işaretleri güvenilirliği arttırarak müşteriler ya da yatırımcılar açısından risklerin ve belirsizliklerin azalmasını, ürünlerin daha kolay benimsenmesini sağlamaktadır. Dolayısıyla bu kuram aracılığıyla da itibarın etkenlerini açıklamak mümkündür.

Kaynak tabanlı bakış kuramcıları, başarının kritik faktörleri olarak şirketlerin ayırt edici kaynaklarına ve yeteneklerine vurgu yaparlar. Bu perspektiften kurumsal itibar, bir kurumun uzun vadede rekabet üstünlüğü sağlayacak stratejik bir soyut kaynağını ifade etmektedir ve itibarın sonuçlarını açıklamada yarar sağlamaktadır.

Bu çalışmada kurumsal itibar son olarak paydaş kuramı perspektifinden açıklanmaya çalışılmıştır. Bu yaklaşıma göre, toplumun çıkarlarını gözeten ve paydaşlarına karşı sorumluluklarını yerine getiren şirketler kurumsal itibarlarını güçlendirebilirler.

Öte yandan, itibar kavramı çeşitli disiplinler arasında etkileri ve sonuçları açısından farklılık göstermektedir. İktisat ve sosyoloji gibi disiplinler kurumsal itibar oluşumunu açıklamaya çalışırken; stratejik yönetim, pazarlama, örgütsel davranış ve muhasebe gibi pek çok disiplin olumlu itibarın kurumsal sonuçlarına odaklanmıştır.

Sonuç olarak, itibarın farklı disiplinlerde farklı kuramlara dayanarak ele alınması gerektiği görülmektedir. Bu nedenle bu araştırmada kurumsal itibar ile çeşitli yönetim ve ekonomi kuramları arasındaki ilişkiler analiz edilmiş ve kurumsal itibarın kuramsal dayanakları sunulmuştur. Bunun sonucunda çeşitli disiplin ve kuramlar göz önünde bulundurularak bir itibar modellemesi önerilmeye çalışılmıştır. Bu model çok disiplinli yaklaşımı ile itibar oluşum sürecini daha iyi anlamaya yardımcı olacaktır. Öncelikle iyi bir itibara sahip olmak isteyen şirketlere, kalite işaretleri göndermenin bu hedefe ulaşmadaki önemini göstermektedir. Bu doğrultuda şirketlerin piyasa gücünü arttırma, kurumsal sosyal sorumluluk faaliyetleri gibi konuları dikkate almaları gereklidir. Ayrıca olumlu kurumsal itibarın, paydaş algılarının doğru yönetilmesi sonucunda oluştuğunu göstermektedir. Kurumsal itibarın en önemli sonucu ise, şirketlere farklılaşma yoluyla rekabet üstünlüğü sağlamasıdır. Bu durum olumlu kurumsal itibarın şirketler açısından önemini ve değerini ortaya koymaktadır.

$\mathrm{Bu}$ araştırma ile kavramın yapısının, öneminin, oluşum sürecinin ve sonuçlarının daha iyi anlaşılmasına katkı sağlanmıştır. Ayrıca itibarın oluşum nedenlerini ya da sonuçlarını destekleyebilecek kuramlar sentezlenmiştir. Tüm bu katkılarının yanında çalışmanın birtakım kısıtları da bulunmaktadır. Öncelikle çalışmada itibar kavramı yazında en çok temellendirildiği kuramlar açısından ele alınmış ve önerilen model de bu doğrultuda geliştirilmiştir. Ancak farklı disiplinlere ait başka kuramlarla da itibar kavramı incelenebilir ve itibar oluşum süreci modeli daha kapsamlı hale getirilebilir. Gelecek araştırmaların farklı kuramsal bakış açılarıyla çeşitli şirketlerin itibar oluşum süreçlerini ve sonuçlarını incelemesi konunun daha geniş bir perspektiften incelenmesi açısından faydalı olacaktır. 
Bahar B. / Journal of Yasar University, 2019, 14/55, 226-236

\section{Teşekkür}

Çalışmaya yorumlarıyla destek olan değerli hocam Prof. Dr. Aylin Ataay Saybaşılı'ya katkıları için teşekkür ederim. 


\section{KAYNAKÇA}

Aydemir, B. A. (2008). İşletmelerin yeni rekabet aracı olarak kurumsal itibar. ISGUC The Journal of Industrial Relations and Human Resources, 10(2), 27-53.

Barnett, M.A., Jermier, J.M. ve Lafferty, B.A. (2006). Corporate reputation: The definitional landscape. Corporate Reputation Review, 9(1), 26-38.

Barney, J. (1991). Firm Resources and Sustained Competitive Advantage. Journal of Management, 17 (1): $99-120$.

Bartikowski, B., \& Walsh, G. (2011). Investigating mediators between corporate reputation and customer citizenship behaviors. Journal of Business Research, 64(1), 39-44.

Basdeo, D.K., Smith, K.G., Grimm, C.M., Rindova, V.P. ve Derfus, P.J. (2006). The impact of market actions on firm reputation, Strategic Management Journal, 27, 1205-1219.

Bergh, D. D., Ketchen, D. J., Jr., Boyd, B. K., ve Bergh, J. 2010. New frontiers of the reputation-performance relationship: Insights from multiple theories. Journal of Management, 36: 620-632.

Boyd, B. K., Bergh, D. D., \& Ketchen Jr, D. J. (2010). Reconsidering the reputation-performance relationship: A resource-based view. Journal of management, 36(3), 588-609.

Bitektine, A. (2011). Toward a theory of social judgments of organizations: The case of legitimacy, reputation, and status. Academy of Management Review, 36(1), 151-179.

Boyd, B. K., Bergh, D. D., \& Ketchen Jr, D. J. (2010). Reconsidering the reputation-performance relationship: A resource-based view. Journal of management, 36(3), 588-609.

Brammer, S. J., \& Pavelin, S. (2006). Corporate reputation and social performance: The importance of fit. Journal of management studies, 43(3), 435-455.

Brammer, S., \& Millington, A. (2005). Corporate reputation and philanthropy: An empirical analysis. Journal of business ethics, 61(1), 29-44.

Cable, D. M., \& Graham, M. E. (2000). The determinants of job seekers' reputation perceptions. Journal of Organizational Behavior, 21(8), 929-947.

Carmeli, A. ve Tishler A. (2005). Perceived organisational reputation and organisational performance: An emperical investigation of industrial entrprises, Corporate Reputation Review, Vol:8, No:1, 13-20.

Carroll, A.B. (2008). A history of corporate social responsibility: concepts and practices. In Crane, A., McWilliams, A., Matten, D., Moon, J. and Siegel, D. (eds), The Oxford Handbook of Corporate Social Responsibility. Oxford: Oxford University Press, ss. 19-46.

Collis, D. J., \& Montgomery, C. A. (1998). Creating corporate advantage (pp. 71-83). Harvard Business School.

Combs, J.G. ve Ketchen, D.J. (1999). Explaining Interfirm Cooperation and Performance: Toward a Reconciliation of Predictions from the Resource-based View and Organızational Economics. Strategic Management Journal, 20 : 867-888.

Çakır, T. (2009). Kurumsal itibar-örgütsel doku ilişkisine kuramsal yaklaşım-1: Paydaş Teorisi. İstanbul Üniversitesi İletişim Fakültesi Dergisi, (37), 49-64.

Davies G., Chun R., Da Silva, R. V. ve Poper S. (2003). Corporate Reputation and Competitiveness, Routledge, New York.

Deephouse, D. L. (2000). Media reputation as a strategic resource: An integration of mass communication and resourcebased theories. Journal of Management, 26: 1091-1112.

Dörtok, A. (2004). Kurumsal İtibarınızdan Kaç Sıfır Atabilirsiniz? Rota Yayınları, İstanbul.

DiMaggio, P. J., \& Powell, W. W. (Eds.). (1991). The new institutionalism in organizational analysis (Vol. 17, pp. 138). Chicago, IL: University of Chicago Press.

Ertuğrul, F. (2008). Paydaş Teorisi ve İşlemelerin Paydaşları ile İlişkilerinin Yönetimi, Erciyes Üniversitesi İktisadi ve İdari Bilimler Fakültesi Dergisi, 31, 199-223.

Flanagan, D. J., \& O’Shaughnessy, K. C. (2005). The effect of layoffs on firm reputation. Journal of Management, 31 : 445-463.

Fombrun, C.J. ve Shanley, M. (1990). What's in a name? Reputation building and corporate strategy. Academy of Management Journal, 33 (2), 233-258.

Fombrun, C. J. (1996). Reputation: Realizing Value From the Corporate Image. Boston: Harvard Business Scholl Press.

Fombrun, C. J., \& Van Riel, C. B. (1997). The reputational landscape. Corporate reputation review, 1(2), 5-13.

Frederick, C. W. (1994). From CSR1 to CSR2: The Maturing of Business-and-Society Thought, Business and Society, 33 (2).

Freeman, R. E., (1984). Strategic Management: A Stakeholder Approach, Pitman, Boston.

Helm, R., \& Mark, A. (2007). Implications from cue utilisation theory and signalling theory for firm reputation and the marketing of new products. International Journal of Product Development, 4(3/4), 396.

Helm, S. (2011). Employees' awareness of their impact on corporate reputation. Journal of Business Research, 64(7), 657-663.

Karaköse, T. (2007). Örgütlerde İtibar Yönetimi, Akademik Bakış, sayı: 11, 1-12.

King, B. G., \& Whetten, D. A. (2008). Rethinking the relationship between reputation and legitimacy: A social actor conceptualization. Corporate Reputation Review, 11(3), 192-207.

Mahon, J. F., Heugens, P. P., \& Lamertz, K. (2004). Social networks and non- market strategy. Journal of Public Affairs: An International Journal, 4(2), 170-189. 
Meyer, J. W. ve Rowan, B. (1977). Institutionalized organizations: Formal structure as myth and ceremony. American Journal of Sociology, 83(2): 340-363.

Meyer, J.W. ve Scott, W.R. (1983). Organizational environments: Ritual and rationality. Beverly Hills: Sage.

Neville, B. A., Bell, S. J., \& Mengüç, B. (2005). Corporate reputation, stakeholders and the social performancefinancial performance relationship. European Journal of Marketing, 39(9/10), 1184-1198.

Özbağ, G. K. (2016). Rekabet Avantajı Yaratmada İki Temel Yaklaşım; Kaynak Tabanlı ve Endüstri Tabanlı Yönetim Modeli. Yeni Türkiye, 88, 888-899.

Özen, Ş. (2007). Yeni kurumsal kuram: Örgütleri çözümlemede yeni ufuklar ve yeni sorunlar. AS Sargut ve Ş. Özen (Der) Örgüt kuramları (237-331). Ankara: İmge.

Petkova, A. P. (2016). Standing out or blending in? The formation of new firms' legitimacy and reputation under different levels of market uncertainty. Corporate Reputation Review, 19(1), 22-34.

Rindova, V. P., Williamson, I. O., \& Petkova, A. P. (2010). Reputation as an intangible asset: Reflections on theory and methods in two empirical studies of business school reputations. Journal of Management, 36(3), 610-619.

Rindova, V., Williamson, I., Petkova, A., \& Sever, J. (2005). Being good or being known: An empirical examination of the dimensions, antecedents, and consequences of organizational reputation. Academy of Management Journal, 48: 1033-1050.

Ruf, B. M., Muralidhar, K., Brown, R. M., Janney, J. J., \& Paul, K. (2001). An empirical investigation of the relationship between change in corporate social performance and financial performance: A stakeholder theory perspective. Journal of business ethics, 32(2), 143-156.

Tucker, L. \& Melewar T.C (2005). Corporate reputation and crisis management: The threat and manageability of anticorporatism. Corporate Reputation Review, 7, 4, pp. 377-387.

Saylı, H., \& Uğurlu, A. G. Ö. Y. (2007). Kurumsal itibar ve yönetsel etik ilişkisinin analizine yönelik bir değerlendirme. Süleyman Demirel Üniversitesi İktisadi ve İdari Bilimler Fakültesi Dergisi, 12(3).

Seitel, F. (2016). Halkla ilişskiler uygulaması. (Çeviri editörü: Seda Mengü). 12. Basım, Ankara: Nobel Yayınları

Spence, M. (1973). Job Market Signaling, The Quertely Journal Of Economics 87.

Stanaland, A. J., Lwin, M. O., \& Murphy, P. E. (2011). Consumer perceptions of the antecedents and consequences of corporate social responsibility. Journal of Business Ethics, 102(1), 47-55.

Suchman, M.C., (1995). Managing Legitimacy: Strategic and Institutional Approaches, Academy of Management Review, Vol: 20, No: 3, 571-610.

The Huffington Post, (30 Ağustos 2013). The 16 best things Warren Buffett has ever said,. Erişim 12 Ocak 2017, http://www.huffingtonpost.com/2013/08/30/warren-buffett-quotes_n_3842509.html

Ural, E. G. (2002). İtibar Yönetimi Değer Yaratan Bir Halkla İlişkiler Çalışması Olarak İtibar Yönetimi. İstanbul Ticaret Üniversitesi Sosyal Bilimler Dergisi, 83-93.

Walker, K. (2010). A systematic review of the corporate reputation literature: Definition, measurement, and theory. Corporate reputation review, 12(4), 357-387. 